\title{
Front Matter: Volume 9602
}

, "Front Matter: Volume 9602," Proc. SPIE 9602, UV/Optical/IR Space Telescopes and Instruments: Innovative Technologies and Concepts VII, 960201 (10 September 2015); doi: 10.1117/12.2218470

EDIE Event: SPIE Optical Engineering + Applications, 2015, San Diego, California, SPIE. United States 


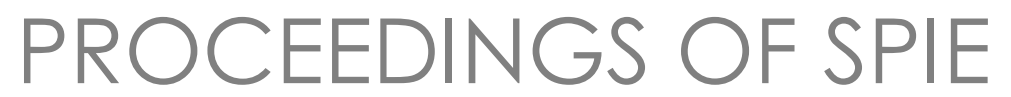

\title{
UV/Optical/IR Space Telescopes and Instruments: Innovative Technologies and Concepts VII
}

\author{
Howard A. MacEwen \\ James B. Breckinridge \\ Editors
}

9-10 August 2015

San Diego, California, United States

Sponsored and Published by

SPIE 
The papers in this volume were part of the technical conference cited on the cover and title page. Papers were selected and subject to review by the editors and conference program committee. Some conference presentations may not be available for publication. Additional papers and presentation recordings may be available online in the SPIE Digital Library at SPIEDigitallibrary.org.

The papers reflect the work and thoughts of the authors and are published herein as submitted. The publisher is not responsible for the validity of the information or for any outcomes resulting from reliance thereon.

Please use the following format to cite material from these proceedings:

Author(s), "Title of Paper," in UV/Optical/IR Space Telescopes and Instruments: Innovative Technologies and Concepts VII, edited by Howard A. MacEwen, James B. Breckinridge, Proceedings of SPIE Vol. 9602 (SPIE, Bellingham, WA, 2015) Six-digit Article CID Number.

ISSN: 0277-786X

ISSN: 1996-756X (electronic)

ISBN: 9781628417685

Published by

SPIE

P.O. Box 10, Bellingham, Washington 98227-0010 USA

Telephone +1 3606763290 (Pacific Time) · Fax +1 3606471445

SPIE.org

Copyright (c) 2015, Society of Photo-Optical Instrumentation Engineers.

Copying of material in this book for internal or personal use, or for the internal or personal use of specific clients, beyond the fair use provisions granted by the U.S. Copyright Law is authorized by SPIE subject to payment of copying fees. The Transactional Reporting Service base fee for this volume is $\$ 18.00$ per article (or portion thereof), which should be paid directly to the Copyright Clearance Center (CCC), 222 Rosewood Drive, Danvers, MA 01923. Payment may also be made electronically through CCC Online at copyright.com. Other copying for republication, resale, advertising or promotion, or any form of systematic or multiple reproduction of any material in this book is prohibited except with permission in writing from the publisher. The CCC fee code is 0277-786X/15/\$18.00.

Printed in the United States of America.

Publication of record for individual papers is online in the SPIE Digital Library.

\section{SPIE. DIGITAL}

Paper Numbering: Proceedings of SPIE follow an e-First publication model. A unique citation identifier (CID) number is assigned to each article at the time of publication. Utilization of CIDs allows articles to be fully citable as soon as they are published online, and connects the same identifier to all online and print versions of the publication. SPIE uses a six-digit CID article numbering system structured as follows:

- The first four digits correspond to the SPIE volume number.

- The last two digits indicate publication order within the volume using a Base 36 numbering system employing both numerals and letters. These two-number sets start with 00, 01, 02, 03, 04, 05, 06, 07, 08, 09, OA, OB ... OZ, followed by 10-1Z, 20-2Z, etc. The CID Number appears on each page of the manuscript. 


\title{
Contents
}

\author{
$\checkmark$ Authors \\ vii Conference Committee
}

\section{SESSION $1 \quad$ ATLAST I}

960202 The JWST science instrument payload: mission context and status [9602-1]

960204 TECHBREAK: a technology foresight activity for the European Space Agency points the way to future space telescopes [9602-3]

960205 A future large-aperture UVOIR space observatory: reference designs [9602-4]

960206 SLS launched missions concept studies for LUVOIR mission [9602-5]

960207 An evolvable space telescope for future astronomical missions 2015 update [9602-6]

\section{SESSION $2 \quad$ ATLAST II}

960208 Overview and accomplishments of advanced mirror technology development phase 2 (AMTD-2) project [9602-7]

960209 Technology development for the Advanced Technology Large Aperture Space Telescope (ATLAST) as a candidate large UV-Optical-Infrared (LUVOIR) surveyor [9602-8]

96020 A ATLAST ULE mirror segment performance analytical predictions based on thermally induced distortions [9602-9]

$9602 \mathrm{OB}$ Correction of an active space telescope mirror using a gradient approach and an additional deformable mirror [9602-10]

9602 0C Optical design of the camera for Transiting Exoplanet Survey Satellite (TESS) [9602-11]

9602 OD ATLAST detector needs for direct spectroscopic biosignature characterization in the visible and near-IR [9602-12]

\section{SESSION 3 UNCONVENTIONAL}

9602 OE Optics of a granular imaging system (i.e. "orbiting rainbows") [9602-13]

9602 OF Design and test of a novel solar imaging payload for small satellites [9602-15] 
9602 OG Characterization of Euclid-like H2RG IR detectors for the NISP instrument [9602-17]

$9602 \mathrm{OH} \quad$ Preliminary results on the EUCLID NISP stray-light and ghost analysis [9602-18]

SESSION 5 TEL TECH

9602 Ol Aluminum mirror coatings for UVOIR telescope optics including the far UV [9602-19]

9602 OK A global shutfer CMOS image sensor for hyperspectral imaging [9602-21]

9602 OM Models for dynamic correlated charge collection effects in thick CCDs [9602-22]

$96020 N \quad$ Proton-induced Random Telegraph Signal in the CMOS imaging sensor for JANUS, the visible imaging telescope on JUICE [9602-23]

$960200 \quad$ Proton irradiation of the CIS115 for the JUICE mission [9602-24]

SESSION 6 SMALLATS AND SUB-ORBITAL

9602 OP Optical design and tolerance analysis of a reflecting telescope for CubeSat [9602-25]

$96020 Q \quad$ Analysis of an optical relay system and integration into a satellite imager [9602-26]

SESSION 7 WFIRST / AFTA

9602 OU Challenges in photon-starved space astronomy in a harsh radiation environment using CCDs [9602-31]

9602 0X Spectral performance of WFIRST/AFTA bandpass filter prototypes [9602-34] POSTER SESSION

9602 OY EUCLID detector system demonstrator model: a first demonstration of the NISP detection system [9602-16] 


\section{Authors}

Numbers in the index correspond to the last two digits of the six-digit citation identifier (CID) article numbering system used in Proceedings of SPIE. The first four digits reflect the volume number. Base 36 numbering is employed for the last two digits and indicates the order of articles within the volume. Numbers start with 00, 01, 02, 03, 04, 05, 06, 07, 08, 09, OA, OB...0Z, followed by 10-1Z, 20-2Z, etc.

Agrawal, Brij N., OB

Allanwood, E. A. H., ON, $0 O$

Allen, Matthew R., OB

Andersen, Geoff, OF

Angarita-Jaimes, Diego, $0 Q$

Asmolova, Olha, OF

Ayala, Michael, 0 l

Balasubramanian, Kunjithapatham, 09, 이

Baldauf, Brian, 07

Barbier, R., OG, OY

Basinger, Scott A., OE

Beaumont, F., OY

Bender, Ralf, $\mathrm{OH}$

Bolcar, Matthew R., 09, OD

Breckinridge, James B., 07

Burgon, Ross, OU

Bush, Nathan, OU

Caillat, L., OG

Chen, Chia-Ray, OP

Chen, Ching-Wei, OP

Chrisp, Michael, OC

Clampin, Mark, 09, OD

Clark, Kristin, OC

Clarke, Andrew, OU

Clémens, J. C., OG, OY

Cohen, Lester M., OA

Collins, Christine, 05

Content, David, OX

Crooke, Julie, 09

Cullum, Martin, 04

Cunningham, Colin, 04

Dailey, Dean R., 07

Dalpiaz, Michael, OC

Del Hoyo, Javier, 01

Detsis, Emmanouil, 04

Dickinson, Thomas, OF

Domagal-Goldman, Shawn D., OD

Dryer, Ben J., OK

Ealet, A., OG, OY

Eisenhower, Michael J., OA

Fabron, C., OY

Feinberg, Lee D., 05, 09, 0A

Ferriol, S., OG, OY

Flannery, Martin R., 07

Fryer, Martin, OK

Garcia, J., OY

Geis, Norbert, $\mathrm{OH}$

Gillard, W., OG, OY

Gow, Jason P. D., ON, 0O, OU
Grassi, E., OY

Greenhouse, Matthew A., 02

Grupp, Frank, $\mathrm{OH}$

Hall, David J., OK, OU

Hennessy, John, 0l

Henry, David, 04

Holland, Andrew D., OK, OM, ON, OO, OU

Hopkins, Randall C., 06

Huang, Winson, OX

Jones, Andrew, 05

Jordan, Douglas, OM

Kamoun, Paul, 04

Kim, Jae Jun, OB

Kotov, Ivan $\mathrm{V}$., OM

Kruk, Jeffrey, OX

Kubik, B., OG, OY

Lagier, P., OG

Leese, M., ON, 00

Lennon, Joseph, OC

Lillie, Charles F., 07

Liu, Alice, 05

Lobb, Dan, $0 Q$

MacEwen, Howard A., 07

Maciaszek, T., OG, OY

Makowski, David, 07

Maldonado, Carlos, OF

Matthews, Gary W., OA

McElwain, Michael W., OD

McHarg, Matthew G., OF

Miller, Kevin H., OX

Moseley, S. H., OD

Murray, Neil, OU

Niclas, M., OG, OY

Nikzad, Shouleh, 01

Nissen, Joel A., OA

Norup Sorensen, A., OG

Noui, Louahab, $\mathrm{OQ}$

Palacios, David, OE

Park, Sang C., OA

Peabody, Hume L., OA

Pike, Andrew, OK

Polidan, Ronald S., 07

Postman, Marc, 09

Pratlong, Jérôme, OK

Prieto, Eric, $\mathrm{OG}, \mathrm{OH}, \mathrm{OY}$

Primeau, Brian, $0 \mathrm{C}$

Quadrelli, Marco B., OE

Quijada, Manuel A., 09, 0l, 0X

Quiller, Trey, OF 
Rafanelli, Gerald L., 07

Raouf, Nasrat, 0 l

Rauscher, Bernard J., 09, OD

Redding, David, 05, 09

Rioux, Norman, 05, 09

Rodriguez-Ferreira, J., OG

Scowen, Paul, Ol

Secroun, A., OG, OY

Seide, Laurie, $O X$

Serra, B., OG, OY

Shaklan, Stuart, 09, 01

Smadja, G., OG, OY

Smith, Dave, $O Q$

Soman, M. R., ON, 00

Stahl, H. Philip, 05, 06, 08, 09

Stahle, Carl, 09, OD

Stark, Christopher C., OD

Stefanov, Konstantin D., OK, OM, ON, 00

Sturm, James, 05

Swartzlander, Grover A., Jr., OE

Swings, Jean-Pierre, 04

Thronson, Harley A., 05, 09, OD

Tilquin, A., OG

Tortora, Jean-Jacques, 04

Weatherill, Daniel P., OM

Winstone, G. P., ON, 00

Wood, Trevor, $0 Q$

Worms, Jean-Claude, 04

Proc. of SPIE Vol. 9602 960201-6 


\section{Conference Committee}

Program Track Chair

Oswald H. W. Siegmund, University of California, Berkeley

(United States)

Conference Chairs

Howard A. MacEwen, Reviresco LLC (United States)

James B. Breckinridge, College of Optical Sciences, The University of Arizona (United States) and California Institute of Technology

(United States)

Conference Program Committee

Suzanne Casement, Northrop Grumman Aerospace Systems (United States)

Colin R. Cunningham, United Kingdom Astronomy Technology Center (United Kingdom)

Lee D. Feinberg, NASA Goddard Space Flight Center (United States)

Matthew J. Griffin, Cardiff University (United Kingdom)

David Leisawitz, NASA Goddard Space Flight Center (United States)

Charles F. Lillie, Lillie Consulting LLC (United States)

Jean-Pierre Maillard, Institut d'Astrophysique de Paris (France)

Gary W. Matthews, Exelis Geospatial Systems (United States)

Mark J. McCaughrean, European Space Research and Technology

Center (Netherlands)

Jacobus M. Oschmann Jr., Ball Aerospace and Technologies

Corporation (United States)

Marc Postman, Space Telescope Science Institute (United States)

David C. Redding, Jet Propulsion Laboratory (United States)

Bernard D. Seery, NASA Goddard Space Flight Center (United States)

H. Philip Stahl, NASA Marshall Space Flight Center (United States)

Session Chairs

1 ATLAST I

Matthew R. Bolcar, NASA Goddard Space Flight Center (United States)

2 ATLAST II

H. Philip Stahl, NASA Marshall Space Flight Center (United States) 
3 Unconventional

David C. Redding, Jet Propulsion Laboratory (United States)

4 EUCLID

Howard A. MacEwen, Reviresco LLC (United States)

5 Tel Tech

Gary W. Matthews, Harris Corporation (United States)

6 Smallsats and Sub-Orbital

Suzanne Casement, Northrop Grumman Aerospace Systems (United States)

7 WFIRST / AFTA

Michael Chrisp, MIT Lincoln Laboratory (United States) 